\title{
ERRATA
}

\section{Bacteriostatic and Bactericidal Activities of $\beta$-Lactam Antibiotics Enhanced by the Addition of Low Concentrations of Gentamicin}

GOHTA MASUDA, KISHIO NAKAMURA, TARO YAJIMA, AND KAZUE SAKU

Department of Infectious Diseases and Department of Central Laboratory, Tokyo Metropolitan Komagome Hospital, Bunkyo-ku, Tokyo 113, Japan

Volume 17, no. 3, p. 335, Table 1: Column headings "FIC index ( $\mu \mathrm{g} / \mathrm{ml})$, ," FLC index $(\mu \mathrm{g} / \mathrm{ml}), "$ and "3-h FLC index ( $\mu \mathrm{g} / \mathrm{ml})$ " should read only "FIC index," "FLC index," and "3-h FLC index," respectively.

\section{Effect of Orally Administered Probenecid on the Pharmacokinetics of Cefoxitin}

PETER H. VLASSES, ${ }^{1}$ ANNE M. HOLBROOK, ${ }^{2}$ JOHN J. SCHROGIE, ${ }^{3}$ J. DOUGLAS ROGERS, ${ }^{3}$ ROGER K. FERGUSON, ${ }^{1}$ AND WILLIAM B. ABRAMS ${ }^{3}$

Department of Pharmacy Practice, Division of Clinical Pharmacology, Philadelphia College of Pharmacy and Science, Thomas Jefferson University, Philadelphia, 19107, ${ }^{1}$ and Merck Sharp \& Dohme Research Laboratories, West Point, Pennsylvania $19486^{3}$

Vol. 17, no. 5, p. 847: The above author affiliations are incorrect and should read as follows.

Division of Clinical Pharmacology, Thomas Jefferson University, Philadelphia, Pennsylvania 19107, ${ }^{1}$ Department of Pharmacy Practice, Philadelphia College of Pharmacy and Science, Philadelphia,

Pennsylvania 19104, ${ }^{2}$ and Merck Sharp \& Dohme Research Laboratories, West Point, Pennsylvania $19486^{3}$ 